DOI: https://doi.org/10.29166/tyc.v1i20.2165

\title{
Formas de incendiar el día
}

\section{Juan Carlos Cabezas Aguilar • 2019}

\author{
Quito: La Caída • 94 páginas
}

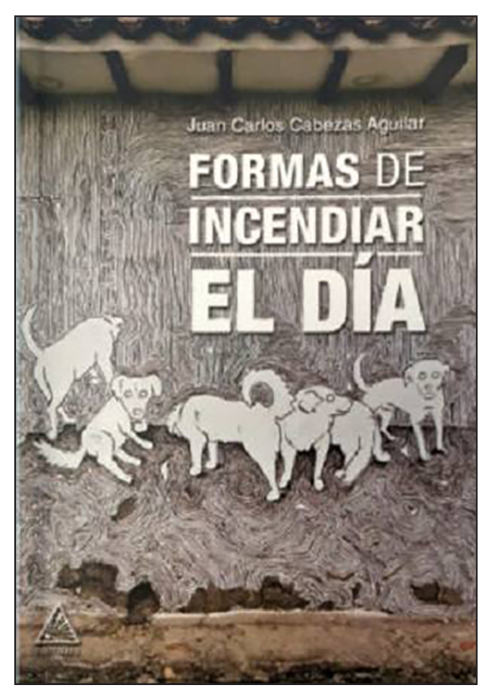

Evocación a los espacios íntimos en los que hombres y mujeres afrontan la vida cotidiana; una mirada sutil y sin complejos a la preparación para representarse y socializar ante el mundo, ese gran escenario... Formas de incendiar el día propone el ensayo -por tanto, nunca algo terminado ni definitivo- de las relaciones de pareja, las relaciones familiares, y la intimidad como una visión apocalíptica de estos tiempos y los futuros.

Los dieciséis cuentos que componen la ópera prima de Juan Carlos Cabezas Aguilar hacen de la dramaturgia un ritual. En escenarios más bien escuetos, el autor genera sentidos acerca de una realidad compartida, forzosamente efímera. No caben en estas páginas ni los símbolos sociales ni una presumida fuerza de la moral, de modo que el lector sale de ellas descreído de la humanidad, con desconfianza y recelo de saber que ha hurgado en la intimidad de otros seres que podrían estar habitando su mismo espacio, apropiándose de ese lugar o bien urdiendo una venganza sin justificaciones.

El carácter coercitivo de los rituales de la sociedad queda interpelado en este libro que explora el límite antes de ser el límite. En él hay elementos como la muerte, que no constituye una tragedia sino apenas un elemento que parece adornar la modorra de la cotidianidad. Vemos, pues, varios cuadros de infidelidad que renuevan a los personajes; al último hombre sobre la ciudad, que no sufre porque su pareja ha decidido dejarse llevar por la visión apocalíptica en la que el cambio climático es el verdadero amo; a un niño que se estrena con irónica ternura en el oficio de asesino...

Algo hay de misterioso atado a la tierra, a la vida y a la muerte que late en estos cuentos: alas gigantes, peces que desaparecen como constatación de la ausencia del ser amado, volver a la casa de los padres solo para constatar la propia ruina... En fin, escenarios donde las relaciones sociales no son más que representaciones sometidas a las reglas ceremoniales que cada personaje pone en la escena con apego a valores no convencionales. La institucionalidad no alcanza a explicar la coherencia entre los comportamientos de los personajes y el sistema de sus normas y valores; por eso, el lector debe abordar estos cuentos sin prevenciones, sin el miasma de la moral ni de las buenas costumbres, porque ellas habrán sido derrotadas.

Los personajes conocen la realidad que los circunda mediante explicaciones que extraen de sus propios procesos de exploración, lo que parece ser una búsqueda constante que atraviesa la obra. La respuesta, sin embargo, nunca llega, o llega fragmentada por una salida no convencional que, unas veces, consterna y otras provoca rencor. Si alguien intentara poblar las dudas de los personajes con una respuesta, 
esta sería el amor, en el sentido que le otorgó Octavio Paz: "La gran subversión de Occidente (...) [que] no niega al otro ni lo reduce a sombra, sino que es negación de la propia soberanía" (Paz, 1995, 4). Aun así, la sentencia parecería insuficiente.

Como se ha dicho líneas arriba, en estos cuentos poco importan los espacios en tanto estos no se humanizan -no por la presencia de los seres que los habitan-, sino que en su misma constitución adquieren valor cuando se convierten en personajes que, con su agencia sobre los hechos y sobre los otros personajes, modifican sustancialmente las acciones. En esos escenarios, que a veces son meras pinceladas, se halla a personajes envueltos en su propio caos y en sus tinieblas, espacios de perdición y de extravío íntimo, al punto de hallar la paz en el estado de coma; de modo que la metáfora del incendio del día, a la que remite su título, parece no solo una contradicción sino una inquietante trampa a la que el lector entra para hallar, sobre todo, formas de apagar la noche.

La capacidad fabuladora de Cabezas no está en discusión -uno de los cuentos que forman parte de esta colección, "El colchón verde", ya fue galardonado en México-; su obra apenas abre las alas y, aun así, al ser una voz nueva en la literatura ecuatoriana, se arriesga a volar sobre la vasta y alta arboleda de la intimidad. Se trata de un vuelo con pocos sobresaltos, conmovedor, sí; envolvente, ágil, sí; aunque, por la contención que late en las palabras, parecería que el autor pudo haber encendido (¿incendiado?) todos los motores para volar más alto.

Santiago Aguilar Morán

Correo: fsaguilar@uce.edu.ec 